石油技術協会誌 第 81 巻 第 5 号 （平成 28 年 9 月） $373 \sim 376$ 頁 Journal of the Japanese Association for Petroleum Technology Vol. 81, No. 5 (Sept., 2016) pp. 373 376

\begin{tabular}{l}
\hline 講 演 \\
Lecture \\
\hline
\end{tabular}

ベストプラクティス追求と技術伝承への取り組み*

\author{
水田富 夫 $^{* * \dagger}$
}

(Received July 21, 2016 ; accepted October 31, 2016)

\title{
Efforts of the best practices pursuit and well engineering technology transfer
}

Tomio Mizuta

\begin{abstract}
While domestic E\&P activity is reduced in recent years in JAPEX and low oil prices continue, drilling and work-over operations which are the valuable opportunities of OJT for all drilling/production engineers are decreasing. Under these circumstances, pursuit of best practices and transfer of well engineering technology are big issues, therefore efforts for those solutions are introduced.
\end{abstract}

Keywords : Best practices pursuit, Well engineering technology transfer, Cementing troubles

\section{1.はじめに}

当社では, 近年国内探鉱活動が縮小される中, 油価の低 迷が追い打ちを掛ける形となって，社内の技術者が実作業 に携わる貴重な機会である国内の坑井作業量が減少してい る。こうした環境下, ベストプラクティスの追求と技術の 伝承は大きな課題となっており, それらの解決に向けた取 り組みを紹介する。

\section{2. 問題点の整理}

当社の抱える技術力低下の問題点の内, 主なものは以下 のとおり。

(1) 危険察知能力が不十分。

・トラブルを未然に防ぐ, あるいは発生しても最小限 の被害でくい止めるための感性が磨かれていないた め, 目前の異常現象に気づかなかつたり, 気づくの が遅れたりする。

・予期せぬ事象やトラブルが発生した際のことを常々 考えてそれらに備えておく習慣が身についていない ため,いざという時に頭の中が真つ白になり, パニッ クに陥つてしまう。

・現場において, 事務所に閉じこもりがちであり, 積 極的に周回を行って状況把握に務めようとしない。

\footnotetext{
* 平成 28 年 6 月 8 日, 平成 28 年度石油技術協会春季講演会作井部門シ ンポジウム「技術の伝承 - 人材育成の在り方」で講演 This paper was presented at the 2016 JAPT Drilling Symposium entitled "Transmission of Expertise - Ways to Streamline Education of Personnel" held in Akita, Japan, June 8, 2016.

** 石油資源開発(侏) JAPEX Co, Ltd.

${ }^{\dagger}$ Corresponding author : E-Mail : tomio.mizuta@japex.co.jp
}

・過去の作業指示書をコピー\&ペーストし, 微修正し て使用するため,頭の中で作業を行うことができず, どこに危険が潜んでいるかイメージできない。また， 過去の数字がそのままであったり，不完全な作業指 示書を作成してしまうことに危機感を抱かない。

(2) 考察力が不十分。

・トラブルが発生しても自ら積極的に考察しようとせ ず，他人任せにしてしまう。

- 人の考えを何の疑いもなく受け入れ, 自分で再考し たり，検証しようとしない。

・1つの考えが頭に浮かぶと, 他の可能性を思い描く ことができなくなる。

・異常現象やトラブルが発生しても, 原因の特定に時 間を要し,あるいは原因の特定をあきらめてしまい, 事態が深刻化してしまう。

(3) 決断力が不十分。

・トラブルが発生した際に, 可能性のある原因を複数 挙げることはできるが, 絞り込むことができないた め対策を立てられない。

・自分の考えに自信を持てないため決断できず, 上位 者の指示なしには何も行動に移すことができない。

(4) 応用力が不十分。

・従来の手法にかたくなに固執しすぎる傾向があり, どういう状況でも, あるいは状況に変化があった場 合でもマニュアルに従って作業を進めようとする。

・ 基本的な考え方やツールスなどの構造を完全には理 解していないため, 想定と異なった状況になった場 合に臨機応変に対応することができない。

(5) 経験や知見の習得が中途半端。 
・周りでエンジニアリングやオペレーションが行われ ていても，自分でしつかりと理解しようとせず，習 得したと勘違いしている。

・後輩を育成する（できる）先輩が限られており，技 術の伝承がなされていない。

\section{3. 問題山積の実例紹介}

上記の問題点が数多く含まれた実例として, 以下に, 2012 年度に掘削された坑井の 9-5/8"ケーシングセメン チング中に発生したトラブルについて紹介する（図 1)。

(1) セメントスラリー後押し中に部分的なパックオフが発 生し, フローアウトが減少, 続いてピットレベルも減 少した。さらにポンプ圧力も急上昇し, 上向き管動中 にもかかわらずWOH が急減少する。

・ドリラーズボックスにいた会社側現場要員や掘削請 負業者側ドリラー, マッドロガーなど, 誰もこの状
況変化に気づかなかつた。

・バイパスプラグの ESC（Stage Cementer）通過に備 えていったんポンプレートを落とした後に元のレー トに戻した直後に発生した現象とは言え, これだけ の状況変化が発生しても誰も異常とは認識できな かった。

(2) 引き続き，フローアウトおよびピットレベルが急減少 し, ポンプ圧力が極端に高いレベルで推移するととも に, WOH は極端に低いレベルで推移した後, 遂にノー リターンとなる。

・ここに至ってやっとトラブルの発生を認識し, ポン プレートを下げる。

・ただし, ノーリターンに至るまでの各種パラメータ の変化に気づいていなかつたため, 何が原因での ノーリターンなのか判断できなかった。

(3) ポンプレートを下げたことでリターンが一部回復した

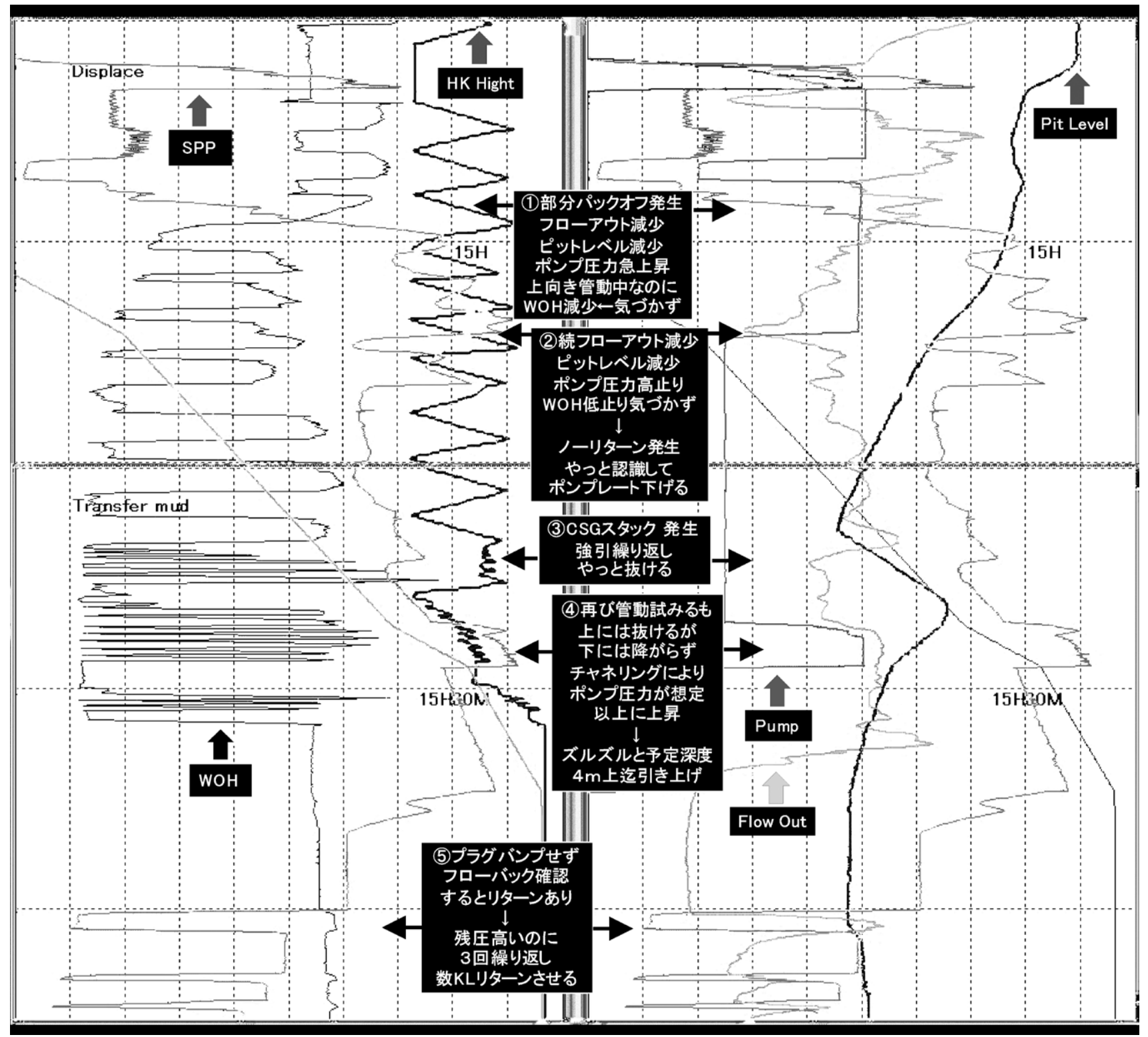

図 1 問題山積の実例 
ため，管動しながら後押しを継続していたところケー シングのスタックが発生する。強引を繰り返してやっ とフリーとなり，予定セット深度まで降下する。

・坑内状況が相当悪化しており，（循環を継続できた ことから）完全ではないものの部分的なパックオフ が発生していることをようやく認識した。

(4) 予定セット深度まで降下できたが，再び管動を試み る。上方には抜けるが下方には下がらず，最終的には 後押しライン長さの関係でこれ以上動かせない位置ま で引っ張り揚げて停管する。同中，ポンプレートを 上げてパックオフの改善を試みるが効果はなく，(リ ターン量に比べて圧力上昇の傾きが大きすぎることか らパックオフが発生していると判断され，後のフロー バック確認時の残圧でも再確認された）セメントスラ リーのアニュラスでのチャネリングの影響でポンプ圧 力が想定以上に上昇する。

・ せっかく予定セット深度まで降下できていたのに管 動を中止する決断ができず，坑内状況が良くなる目 途もないまま再度管動を開始した。

・下方には下がらず，途中で断念することもできず， 結局ずるずると一番高い位置まで引つ張り揚げてし まった。

・そちらに気を取られてしまい, ポンプ圧力が想定以 上に上昇しているのに気づかなかった。

(5) 最大許容量まで後押しするもプラグはバンプせず。フ ローバックを確認するとリターンがあり, 3 回繰り返 して数 $\mathrm{k} l$ リーンさせる。

・なかなか止まりそうにないのに, 必要以上に長い時 間のフローバックを行つた。

・シャットインすると直ちにケーシング圧力が回復 し，しかもセメントスラリーのチャネリングに よって予定以上の差圧があるのを考慮せず，止め る決断ができないまま結局 3 回のフローバックを 行った。

\section{4. 問題解決への取り組み}

2 章に示した問題点は一つ一つが独立したものではな く, 複数の問題点が組み合わさってトラブルが発生し, ま たそれが深刻化するケースが多いと考えられ，3 章で示し た実例は，残念ながらそうしたことを顕著に表している。 問題解決への近道はなく, 地道に, かつ着実に組織全体, および個人のエンジニアリング・オペレーション能力を向 上させなければならない。そのため, 当社では以下のよう な取り組みを行っている。

(1) 計画段階でのリスクアセスメントへの全員参加

・鉱業所, 現場だけでなく, 本社を含めた（国内在住 の参加しうる）坑井作業関係者全員がリスクアセス メントに参加する。

・ 当該坑井のオペレーションの順調な進渉やトラブル の未然防止に努めるだけでなく, 個人の考察力, 危 険察知能力や積極性の向上に活用している。
(2) 作業指示書の現場以外での確認

・本来は現場で完結すべきものであるが，鉱業所や場 合によっては本社による確認を行うことによって, ともすれば当面の作業にばかり気を取られ視野が狭 くなりがちな現場が適切なオペレーション手法を選 択するのをサポートすると共に, 現場から離れた場 所で勤務するエンジニアにもノウハウを伝承するこ とでオペレーション能力の向上を図っている。

・オペレーション終了後には作業指示書と実績を照合 してレビューし，何がベストプラクティスであるの か考察してコメントを入力し, 次井以降への備忘録 として利用している。

(3) ウェルサイトドリリングエンジニアマニュアルの作成 ・現場や鉱業所における先輩から後輩への経験や知 見，ちょつとしたノウハウの伝承を目的とし，先輩 から学んだことを文章にまとめてネットワーク上で 共有している。

・現場や鉱業所で勤務する機会は限られており, 1 対 1 の伝承ではもつたいないこと，および後輩に伝承 する（できる）先輩が限られていることが導入の理 由である。

(4) 決断支援データベースの整備

・トラブルを未然に防ぐこと，および発生したトラブ ルを早期に解決することを目的として過去の事例を データベース化し，キーワードによって容易に検索 できるようにして利用している。

・過去の経験が十分に活用できていなかったことや, 類似したトラブルの発生を防止できなかったことが 導入の理由である。

(5) ポストジョブミーティングの実施

・坑井作業が終了する毎に, (必要に応じてサービス コントラクターも含めた）関係者によるレビューを 行っている。

- PDCA（Plan・Do・Check・Action サイクル）を回す ことによって，良かった点は評価して次回以降も継 続して実施することとし, 改善すべき点や反省すべ き点はしつかりと検討を行って対策を施し, 次回以 降に生かしたり，同じ失敗を繰り返さないようにし ている。

(6) 本社での坑井作業関係者による連絡会開催

- 改組により事業本部制となって坑井作業関係者が分 散したことを受け, 各事業本部間の情報交換, およ びトラブルなどに関する意見交換を目的として，週 1 回のペースで開催している。

・違つた立場, 違つた視点で物事を考えることによつ て, 当事者（もしくは 1 人）では気づかなかつた問 題点が指摘されることがあり, その場で議論して 解決したり, 解決できなかった場合はいったん持 ち帰つて次回の連絡会で検討結果を披露したりして いる。

(7) 他所のデイリーオペレーションレポートの読み合わせ 
・生の教材であるデイリーオペレーションレポートを 有効活用するため, 当日の他所レポートの読み合わ せを行っている。

・若手にとってはオペレーション上の疑問点や不明点 をクリアにすることができ, 中堅からべテランに とっては古い記憶を呼び覚まして過去の教訓を若手 に伝えたり，手順や手法を再確認できるといった効 果がある。

\section{5. プロダクションエンジニアリング 部門強化に向けた取り組み}

これまでは，基本的にドリリングエンジニアリング（以 下 DE）部門に関する問題点, および解決に向けた取り組 みを紹介してきたが, プロダクションエンジニアリング(以 下 PE）部門も同様な問題を抱えており, それらの解決に 向けて同部門の強化に本年度より本格的に取り組み始めた ことから，ここではそれらについて簡単に紹介する。

(1) 背 景

・坑井作業全体を俯瞰（コントロール）できる人材が 不足している。

・経験不足，検討不足に起因するトラブルが多い。

(2) 目 標

- 生産量増大のための専門技術の維持・強化を行い国 内外事業へ貢献する。

(3) 目標達成に向けて

- 国内外事業への坑井・生産技術サポートを行いなが ら, 3 年以内に $\mathrm{PE}$ 部門の組織運営を確立し, 国内 外油ガス田の生産量増大を図る。

・PE 部門に係る組織および職掌の確立, ロードマッ プの作成, および蓄積した技術の整理を行い, 向か うべき方向性を定める。さらに，PE 部門を拡充し て国内外の坑井・生産技術をリードしつつ技術の伝 承を行い，ガイドラインの作成などを行う。
・若手 PEリーダーを育成して海外オペレータ業務へ の派遣などを行う。

(4) 業務範囲

・坑井を中心にその上下流にまたがる業務。主業務と しては, 坑井生産能力改善, 坑井刺激, 人工採油, 坑井仕上げデザイン，生産テスト（DSTを含む） などの検討，および実施。

- 技術研究所主導の R\&D 業務の内, 坑井作業に係る 業務。

(5) 課 題

・PE 部門はこれまでに 2 度設置を試みたが，いずれ も $2 \sim 3$ 年程度しか継続できなかつた。

・組織のリーダー, 職掌, ミッションを明確にし, 組 織継続のモチベーションを持ち続けられるよう坑井 作業量を維持する必要がある。

・人材の確保は質, 量ともに最重要課題である。

\section{6.おわりに}

$\mathrm{DE}$ 部門の問題解決への取り組みは数年前より開始して おり，徐々にではあるが効果が現れてきていると実感して いる。ただし，念を押すまでもなく地道な努力が不可欠で あり，今後も継続していくことが肝要である。

PE部門の強化については取り組み始めたばかりであり, 強い意志を持って目標の実現に向かって尽力していかなけ ればならない。

DE 部門と PE 部門はそれぞれが完全に独立した分野で はなく, 生産性の良い坑井に仕上げ, 生産量を回復させた り維持・増大させるには両部門の連携が必須である。坑井 作業量が減少していく環境下，そうした理由から将来的に は両部門の融合を目指しており, 両部門の各要素技術を 1 人で横断的に取り扱えるハイブリッドエンジニアを育成す ることが重要なテーマであると考えている。 